\title{
IMPACT OF PROFIT-LOSS SHARING FINANCING ON POVERTY ALLEVIATION OF SHRIMP FARMERS IN TULANG BAWANG REGENCY (CASE STUDY: KEMITRAAN BUMIDIPA)
}

\author{
Shofiyanto ${ }^{1}$, Muhammad Findi. ${ }^{2}$, Salahuddin El Ayyubi \\ ${ }^{1}$ Faculty of Economics and Business, Universitas Gadjah Mada, Indonesia \\ Jln. Sosio Humaniora No.1 Bulaksumur, Yogyakarta, 55281 Indonesia \\ Correspondence E-mail: shofiyanto.sy2@gmail.com
}

${ }^{2}$ Faculty of Economics and Management, Institut Pertanian Bogor, Indonesia

Jl. Agatis, Center Wing 2nd Floor, IPB Dramaga Campus, Bogor - West Java - Indonesia

Correspondence E-mail: muhammadfindi73@yahoo.com

Received: July 2017; Accepted: October 2017

\begin{abstract}
This research aimed to describe the core values of Kemitraan Bumidipa as sharia microfinance program that applies profit-loss sharing scheme, to elaborate the main obstacles that might cause the failure of the program, to analyze the effectivity of its financing, and to analyze the impact of financing on poverty alleviation of shrimp farmers in Rawajitu Timur District, Tulang Bawang Regency. Descriptive analysis, qualitative analysis and poverty indices are used as the analysis methods. The result shows that, on the one hand, the core values of Kemitraan Bumidipa are the real profit sharing system, professional financial services, and the investment guarantee model for its financing. On the other hand, the risks faced by the program are the the unstable environment of shrimp farming, technical problems, the shrimp's price fluctuation, and moral hazard behavior. According to effectivity analysis, overall this program has been effective. Based on poverty indices result, sen index of farmers increase after becoming members of Kemitraan Bumidipa as the result of the failure of farmers' cultivation. As recommendation, it should be a supervision mechanism to prevent the members from moral hazard act and it's neccessary for further research particularly related to the unstable environment of shrimp farming and the fluctuation of shrimp's price.
\end{abstract}

Keywords: effectivity, Islamic microfinance, poverty, profit-loss sharing financing, Sen Index

JEL Classification: F10, F15, C43

Abstrak: Penelitian ini bertujuan untuk mendeskripsikan nilai inti dari Kemitraan Bumidipa sebagai program microfinance syariah yang menerapkan skema bagi hasil, menganalisis efektifitas pembiayaannya, menguraikan hambatan-hambatan yang dapat menyebabkan kegagalan program, serta dampak pembiayaan terhadap pengentasan kemiskinan petani tambak di Kecamatan Rawajitu Timur, Tulang Bawang. Metode analisis yang digunakan adalah analisis deskriptif, analisis kualitatif dan indeks kemiskinan. Hasil penelitian menunjukkan bahwa, di satu sisi, nilai inti dari Kemitraan Bumidipa adalah sistem bagi hasil berbasis profit aktual, pelayanan finansial profesional, dan adanya model jaminan investasi. Sementara itu, risiko-risiko yang dihadapi Kemitraan Bumidipa adalah ketidakstabilan lingkungan budidaya udang, faktor teknis, ketidakstabilan harga udang, serta penyimpangan dari anggota. Menurut analisis efektivitas, secara keseluruhan pembiayaan sudah tergolong efektif. Sementara menurut analisis indikator kemiskinan, justru terjadi kenaikan pada sen index (P2) setelah petani tambak menjadi anggota kemitraan sebagai akibat kegagalan budi daya. Sebagai rekomendasi, perlu adanya mekanisme pengawasan untuk mencegah anggota dari perilaku menyimpang serta perlu adanya penelitian lanjutan terutama yang berhubungan dengan ketidakstabilan dari lingkungan budidaya dan harga udang.

Kata Kunci: efektivitas, microfinance syariah, kemiskinan, pembiayaan bagi hasil, Sen Index Klasifikasi JEL: F10, F15, C43 


\section{INTRODUCTION}

Indonesia is a maritim country that possess great potential in the fisheries sector. It can be seen from the fact that Indonesia is the largest archipelagic state in the world which has 17,504 islands and coastline length of 104,000 km (Bakosurtanal 2006). The total area of sea itself is around 3,544 million $\mathrm{km}^{2}$, or approximately $70 \%$ of the territory of Indonesia (Ditjen P2HP, 2011). These geographical conditions show that Indonesia has a large fishery resources.

In fact, contradictive condition happened with coastal societies as main actors of fisheries sector compared to its potential. In 2011, the Central Statistics Beaureau (BPS) recorded the number of poor fishermen in Indonesia reached 7.87 million, or about $25.14 \%$ of its total poor population (Jannah 2014). According to Fauzi (2000), it is generally recognized that the main cause of global fisheries crisis is the poor management of fisheries that can be seen from the prominent phenomena, namely overcapacity and habitat destruction. These factors then could arise several problems, such as the massive subsidies, poverty, overfishing, etc. This condition becomes a big challenge for anyone who is involved on fisheries sector, especially for the developing country like Indonesia where the social, political, economic, and demographic condition that doesn't support the fisheries development. Therefore, it is not surprising as the decades of this nation's independence, the fisheries sector has not shown its movement, although the physical and geographical potential of fish resources in Indonesia is far better than countries in Asia.

This poverty problem could also be determined as the result of the limited access to capital. There is a reciprocal relationship between the poor when associated with access to capital. The coastal societies couldn't access the capital because they are poor, and as they are not able to access it they remain poor. According to Maarif (2008) in Ariansyach (2009), some factors that causes the poverty on coastal societies are the limited access to capital and cultural subsistence or work merely to meet the daily basic-needs.

There are some definitions related to the term of poverty. According to Central Bureau of Statistic (BPS), poverty is seen as an economic inability to meet the basic needs of food and nonfood categories, measured by expenditure approach. Therefore, BPS concluded that the people are categorized as poor if the average of their monthly-expenditure per capita for each month is below the poverty line. The poverty line is the combined concept of Food Poverty Line (GKM) and Non-Food Poverty Line (GKNM). While the Board of National Population and Family Planning (BKKBN) defines poverty as a family welfare concept. BKKBN devides the criteria of families into five stages: PreProsperous Family (Pre-KS), Prosperous Family I (KS I), Prosperous Family II (KS II), Prosperous Family III (KS III), and Prosperous Family III Plus (KS III-Plus). In this case, BKKBN defines Preprosperous family as a very poor family and Prosperous Family I as poor family (Beik et al. 2013).

Sajogyo (1996) revealed that poor concept is not limited to the inability to meet the the physical or biological needs, but also related to the inability of a person to live and function as "standard" in their communities. One consequence of this concept is that the poverty measurement becomes relative, which is changed from time to time. This change is not only about the price change, but a change in what people need for a decent live from time to time in a developing society.

The concept of poverty in Islam refers to the notion of absolute poverty has been evolved which is measured by the inability to meet basic needs. Furthermore, the Islamic concept of 
absolute poverty is built on two indicators of material poverty and spiritual poverty. Material poverty is based on the inability to meet the material needs, while the spiritual poverty is based on the inability to meet the minimum spiritual needs such an implementation of compulsory worship. When a household experiences material poverty and spiritual poverty, the household can be said to suffer absolut poverty (Beik et al., 2013).

Actually, various attempts have been undertaken by the government in order to tackle this matter. Several policies were implemented directly, for instance the expansion of the industry, modernization of fishing gear, and capital assistance such as Farming Credit (KUT), Business Credit (KUR), Credit for Micro and Small Business (KUMK), Community Development Partnership Program (CSR). Unfortunately, those programs were still aid purpose only, rather than the financing program.

While the low access of coastal societies to capital and market have caused them prefer to deal with non-formal financial institutions such a loan shark. It just trapped them into more difficult situation. This condition could be a vicious cycle that causes powerlessness of coastal societies (Ariansyach, 2009).

The shortage in the credit system that has been done by the government and financial institutions should be evaluated in order to get other financing alternatives that are better suited for fisheries sector. Credit or financing system offered should be relevant to the conditions of coastal communities. One of the solutions for the problem is Islamic financing system. Islamic financing system oriented on improving the welfare may give a new hope to the future of farmers, particularly in the field of fisheries.

According to Undang-Undang No. 21 Tahun 2008 about Islamic Banking, financing is the provision of funds or bill equivalent with the form of the profit and loss sharing in the form of mudharabah and musyarakah, leasing transactions in the form of Ijarah or hire purchasing in the form of Ijarah muntahiya bittamlik, purchasing transactions in the form of murabaha, salam, and istishna', debt transaction in the form of receivables qardh and leasing service transaction in the form of ijarah for multiservice transactions based on agreement between Islamic Bank and / or the Sharia Business Unit (UUS) and other parts that obligates the part required financing and / or given the facility of funds to repay the funds after a certain period of time in exchange for ujrah, without compensation, or profit sharing.

In general, the Islamic financial system generates two types of financing design, those are debt financing and equity financing (Ghafar and Ismail 2006). Financing in the form of debt such as murabahah and Ijarah use mark-up schemebased, whereas capital financing such as mudharabah and musharakah use the profit-loss sharing (PLS). Profit-loss sharing itself as a form of financing is preferred because it can boost the economy in the real sector and contains the values of justice, especially in the distribution of profits and losses for the parties involved.

Based on its history, the profit-loss sharing scheme in business partnership actually has been implemented long time ago. It is commonly conducted by people of Mecca and Medina long before Islam was revealed through the Prophet Muhammad. In Medina, profit-loss sharing system was widely applied in the form of cooperation on agriculture and trading sector as well as livestock raising. Afzalurrahman (1997) stated that the Quraysh had excellent trade knowledge and gain a huge profit from it. Trading was performed in various forms, as well as its business organization. Syirkah (cooperation) was conducted in several forms, where the owners of capital could be directly involved in the business or simply become sleeping partner, 
and that way, they shared in the profits and losses (mudaraba).

In Indonesia, the practice of business activities based on Islamic principles has also already been applied by farmers like maro and mertelu system. This makes the application of the Islamic financing system seems not to be a difficult thing for farmers, but provides a greater profit for them and offer more justice for all parties involved (Anjani, 2013).

Profit-loss sharing system in the financial sector (bank) was begun with the establishment of a local bank in Mit Ghaur Village in 1963. Although closed after several years, it inspired the first conference of Islamic Economics in Mecca in 1975. Then the Islamic Development Bank (IDB) was born and followed by the establishment of Islamic financial institutions in various countries. In Indonesia, sharia bank was first established in 1992, namely Bank Muamalat Indonesia (Soemitra, 2009). Furthermore, the development of Islamic financial institutions in Indonesia is continued widely till now.

Yousfi (2013) stated that the financing contract using profit-loss sharing principle, especially mudharabah is able to overcome the problem of moral hazard in the financing because it provides a very strong incentive mechanism in cases where there is a risk of failure of an organization. This kind of funding would trigger the fund manager (mudharib) to give maximum effort on the business.

However, the profit-loss sharing model may face some obstacles on its implementation. According Sutriso (2008), the profit-loss sharing system is still very weak compared to mark-up financing system such a murabahah. It is inseparable from the constraints in implementation, both in terms of Shahibul mal (investor) and mudharib (client). The constraints faced by Shahibul mal is related with agency problem, high level of risk, technical terms, financing that is only on short term, and the ineffectiveness of profit-loss sharing financing. While the constraints on mudharib includes moral standards, lack of freedom in term of running the business, as well as the cost and efficiency problems. These constraints will certainly affect the performance of the financing itself.

Various studies discussed about microfinance and its effect on various aspects of the economy. Some of the research related to the impact of microfinance program on coastal societies income. Ariansyach (2009) stated that microfinance program that gave capital to fishermen had real influence on the enhancement of their income. There are significance rise of participants' business revenue as the result of capital increase from the program. Another study, conducted by Rodiana (2014), discussed about the effectivity of the sharia microfinance program that apply murabahah and yarnen on farmers. The result showed that Implementation yarnen system in this program was been effective at all stages of financing and had positive impact on its members' business.

Effendy (2013) compared the role between conventional microfinance and sharia microfinance in case of poverty alleviation. The result revealed that both types of institutions had a positive effect on poverty reduction. But the effect of the Islamic financial institutions was slightly better than conventional financial institutions. Filtration system used by Islamic microfinance had a significant impact on its ability to avoid credit risks faced by conventional one, as well as client business development.

Other studies try to analyze the effectivity of financing, especially in microfinance field. According to Anjani (2013), basically the effectivity refers to a success or achievement of objectives. Effectiveness can be described by 4 criteria (Agustina, 2010): 
1. Doing things right according to the plan and the rules.

2. Achieving a level above the competitors or able to be better than competitors.

3. Giving the results when what is conducted provide benefits to people other party.

4. Able to handle future challenges.

According to Aryanti (2006) in Azzahrah (2014), effectivity of financing could be assessed from the procedure of financing and its impacts to business conditions. Financing procedure consists of application, lending and repayment process, while the financial impacts could be measured from the increase of revenue, profit, and business conditions. According to Ita and Rahman (2011), there are three important stages in the Mudharabah financing procedure. Those are the analysis and financing evaluation, the application and approval of financing.

Islamic financing model that applies profitloss sharing has been widely developed in Indonesia. Especially in term of microfinance for coastal societies, there are a lot of financing schemes provided to set an inclusive and affordable financial services. One of those is a financing program for shrimp farmers operating in the East Rawajitu District, namely Kemitraan Bumidipa. This is a financing program for shrimp farmers that applies profit-loss sharing system in the district of East Rawajitu, Tulang Bawang Regency.

Therefore, it's needed to assess whether the financing system for fisheries business has been effective, in term of being able to afford them and able to provide the benefits. It's also needed to be examined whether the profit-loss sharing financing is able to give positive effect on the welfare of the fisheries business, and contribute on poverty alleviation on this society. Thus, purposes of this research are formulated as follow:
1. Describe the background, system, core value of Kemitraan Bumidipa as one of the sharia microfinance program that applies profit-loss sharing scheme.

2. Elaborate the main obstacles that might cause the failure of the program

3. Analyze the effectivity of financing based on its member perspective.

4. Analyze the impact of profit-loss sharing financing on poverty alleviation of shrimp farmers in Rawajitu Timur District, Tulang Bawang Regency.

\section{RESEARCH METHOD}

\section{Population and Sample}

The research was conducted at Kemitraan Bumidipa Program that operates in the East Rawajitu District, Tulang Bawang Regency, Lampung Province. This study uses primary data and secondary data that are both quantitative and qualitative. Primary data were obtained from in-depth interviews with key informants and respondents. There are 5 Informants in this study. One of them is from the management of Kemitraan Bumidipa and the rest are from external parties that is still related to the program. The respondents consisted of 100 members of the program. Secondary data were obtained from the Ministry of Fisheries and Maritime Affairs, the Central Bureau of Statistics, books, journals, theses related and other data that support the availability of data.

\section{Data Analysis}

Miles and Huberman Model

This study used a qualitative approach to the analysis of Miles and Huberman Model, especially in processing the results of the key informant information and related literature. Miles and Huberman (1984) in Sugiyono (2010) suggested that activity in the qualitative data analysis performed interactively and lasted 
continuously until it is completed, so that the data is already saturated. Data analysis stages are consisted of data reduction, data display, and conclusion drawing / verification.

\section{Likert Scale}

Likert scale are used to measure attitudes, opinions and perceptions of a person or group of people on social phenomena. This is the consideration of the use of Likert scale in this study. The next step is to do the scoring on the data to be classified and grouped in the categoryspecific categories. The determination of the total score for each category is as follows:

\section{Total Score $=$ total respondent's $\mathrm{x}$ score per category}

The respondents' assessments for the effectivity of Kemitraan Bumidipa financing could be examined from 4 aspects, namely the application process, realization of financing, repayment of financing, and its impact perceived by members. The total score for each procedure is ranged between 100 and 300. This score is obtained by calculating the lowest and highest scores with the number of questions in each procedure and also the number of respondents. While the interval for each category is obtained from the difference between the total score divided by the highest possible response categories and it's then reduced by 1 (Sugiyono 2011).

$$
\text { Interval }=\frac{\text { Max Score-Min Score }}{\text { Answer Category }}-1
$$

The interval for every category is 199 . Based on this result, the categories are classified as follows:

1. Not effective if total scores between 300 and 499

2. Quite effective if total scores between 500 and 699

\section{Effective if total scores between 700 and 900}

The results of the assessment will provide a conclution of the effectivity for every stage of financing managed by Kemitraan Bumidipa to their members. Finally, it will be give some recommendations that might be useful to improvement of the program.

\section{Poverty Analysis}

\section{Headcount Ratio}

Headcount Ratio Index $(\mathrm{H})$ measures the number of shrimp farmers whose income was below the poverty line as a percentage of the population observed. The poverty line used were household poverty line per month, which is calculated based on individual poverty line and then converted to household poverty line per month. Formula for measuring headcount ratio is as follows:

$$
\begin{aligned}
& \qquad \mathrm{H}=\frac{q}{n} \\
& \begin{array}{l}
\mathrm{H}=\text { here: } \\
\mathrm{q}=\text { number of shrimp farmers that was } \mathrm{q} \\
\text { below the poverty line }
\end{array} \\
& \mathrm{n}=\text { number of observation }
\end{aligned}
$$

The family poverty line is obtained by multiplying the poverty line per capita per month with the average of family size. The poverty line of Tulang Bawang Regency in 2014 is Rp 307,348.96, - per capita per month. The average amount of household is the result of the ratio of the total population by the number of households in Tulang Bawang regency. In 2014, the total population of Tulang Bawang regency is 423,710 inhabitants and the number of households is 116,919 .

The average amount of household = Total population Tulang Bawang / Number of households: $423,710 / 116,919=3.624$ 
So, the household poverty line of Tulang Bawang Regency is:

$\mathrm{K}=$ the poverty line per capita per month $\mathrm{x}$ the average amount of household

$=\operatorname{Rp~307,348.96,~-~x~} 3.624$

$=\operatorname{Rp} 1,113,833$, - per household per month (3)

The purpose of the headcount ratio index as analysis tools in this research is to measure the number of shrimp farmer households who are under the poverty line and its changes after they got financial services from the program.

Poverty Gap Index and Income Gap Index

The poverty gap index and income gap index measure of the intensity of poverty. It is defined as the average poverty gap in the population as a proportion of the poverty line. The formula is as below

$$
\mathrm{P}_{1}=\sum_{i=1}^{q} \frac{z-y i}{q}
$$

Where:

P1 = Poverty gap Index

$Z=$ poverty line

yi = income of household-i

$q=$ number of households that are below the poverty line (poor households)

$$
\mathrm{I}=\sum_{i=\in \mathrm{S}(\mathrm{z})} \frac{g i}{q z}
$$

Where:

$$
\begin{aligned}
\mathrm{I} & =\text { Income gap ratio } \\
\text { gi } & =\text { the gap between poverty line and } \\
& \text { poor household income } \\
\mathrm{q} & =\text { number of poor households } \\
\mathrm{z} & =\text { poverty line }
\end{aligned}
$$

Sen Index

Sen Index of Poverty or poverty severity index is used to explain the inequality of income among the poor (Clark et al., 1981). Formula for Sen Index:

$\mathrm{P}_{2}=\mathrm{H}\left[\mathrm{I}+(1-\mathrm{I}) G_{p}\right]$

Where:

$$
\begin{gathered}
H=\text { Headcount ratio } \\
\mathrm{I}=\text { Income-gap ratio } \\
\mathrm{Gp}=\text { Gini coefficient of poor households }
\end{gathered}
$$

Research Framework

Fisheries is the sector that has huge potential in Indonesia. It can be understood from the fact that Indonesia is a maritime country that is rich in its resources. One of the main important factors needed by fisheries business to support the development of this sector is capital. However, characteristics of coastal societies that is still poor created a barrier to access it. Therefore, it's necessary to find a financing model that is affordable and suitable with the criteria of coastal societies.

Profit-loss sharing financing applied by sharia microfinance institution is believed to be one of the solution for this problem. This scheme offers a fair transaction for fisheries business as it shares risks and profit that may happen in business. In the end, there is a need to evaluate the effectiveness of the financing that has been implemented in every stage in order to assess its attainment. Besides, It should be outlined the factors that could cause the failure of the program. Finally, it will be analyzed how profitloss sharing financing might contribute on poverty alleviation for coastal societies as it is expected to increase their income and business.

\section{RESULTS AND DISCUSSION}

\section{Description of Kemitraan Bumidipa}

Dipasena is a shrimp aquaculture area located in East Rawajitu District, Tulang Bawang Regency, Lampung with 16250 hectares on width. This area is divided into eight villages, namely Bumi Sentausa, Bumi Dipasena Utama, Bumi Dipasena Agung, Bumi Dipasena Jaya, Bumi Dipasena Mulia, Bumi Dipasena Makmur, Bumi Dipasena Sejahtera, and Bumi Dipasena 
Abadi. Every village is consisted of 2 blocks and each of them is divided into 6 sub-bloc (equivalent with RW). Dipasena was operational area of P.T. Dipasena Citra Darmaja partnership formerly. However, as the company went bankrupt, Dipasena is managed independently by the farmers there.

Over the past few years, Dipasena farmers got major problem related to shrimp's cultivation. This is mainly due to difficulty in getting access to capital from financial institutions for the cultivation, in addition to the lingering illness of shrimp aquaculture. The absence of capital is caused by the difficulty for farmers which are poor in majority to provide required collateral for shrimps' cultivation. These constraints led to the decreased of farmers' productivity.

This problem, then triggered P3UW (Association of Dipasena's Shrimp Farmers) as the organization of shrimp farmers there to set the right partnership model to be applied for the shrimp farmers. After conducting long study and discussion, P3UW through KPBD (Cooperative of Dipasena's Shrimp Farmers) established P.T. Bumidipa in 2013. The management of this company are the professionals recruited by P3UW. P.T. Bumidipa has a working structure that provides services in three main areas, namely:

a. Operations and Marketing. The services provided in this area include:

1. Cultivation, harvesting and postharvesting.

2. Consulting services to partners and farmers regarding shrimp cultivation.

3. Maintenance of production facilities.

4. Research and development

b. Finance and others. The service provided in this area include:

1. Administration and investment.
2. Transaction management for farming and non-farming field.

3. Administration for supporting facilities of production.

c. Community development. The services provided in this area are include:

1. Non-farming management

2. The development of education and health quality of society

3. Maintenance of public and social facilities

4. The development of social environment

P.T. Bumidipa, along with P3UW and KPBD then, set a program called Kemitraan Bumidipa. It provides financing addressed for the shrimp farming in Dipasena. It applies profitloss sharing system based on Islamic teaching. Profits are shared between the investors, management, and farmers. The program is committed on welfare of farmers in the partnership. It could be seen from the percentage of profit for shrimp farmers, which is the highest one among other parties. The ratio of profit is set on $80 \%$ for farmers, $15 \%$ for investors, and $5 \%$ for the management of the program and it's based on net profit of the farming-business.

Kemitraan Bumidipa also shows commitment in enforcing the sharia compliance with imposing zakat for farmers at the end of every business period. The amount of zakat is according to money zakat. The proportion of zakat is $2.5 \%$ of gross profit from shimp farming business.

On its management, the capital given to the farmers isn't by money, but in the form of saprotam (input for shrimp cultivation) such as shrimp seed, shrimp feed, and fertilizer. It's given regularly based on the needs of farmers during cultivation period. The purpose of this mechanism is to ensure that the capital provided is used for productive purposes and facilitate the partners so that they are no longer need to think about procurement of saprotam. Besides, 
management of Kemitraan Bumidipa is committed to provide cheap input for shrimp cultivation, but high on its quality. As this input will be operational cost for Farming business, the less of the cost the higher the profit could be. Indeed, that become an advantage for the members of Kemitraan Bumidipa.

In order to deal with the investment guarantees problem, management of program set CRU (Reserve of Business Ratio) fund, which is imposed on members who succeed in their business. The CRU ratio itself is $10 \%$ of operational cost. This fund is used to cover the losses from failed members in the business, so that they don't bear the loss and capital isn't reduced. The CRU mechanism is a form tabarru (bear each other) and ta'awun (help each other) among farmers.

Furthermore, to overcome the weak accounting system, Kemitraan Bumidipa collaborates with Sharia bank in managing its capital. With this collaboration, the program will be able to manage its finance to be accountable, professional, and transparent for shrimp farmers. The benefit for Sharia bank is from investors endowment fund as well as cash transactions in the program.

The overall calculation of profit-loss system in Kemitraan Bumidipa Program is described in figure 1. Based on the figure, total revenue of farmers' business is deducted by operating costs of cultivation to get gross profit, which further reduced again by CRU pieces $(10 \%$ of operational cost) and zakat (2.5\% of gross profit). The result of this reduction, called net profit, is then shared with a percentage of $80 \%$ for farmers, $15 \%$ of investors, and $5 \%$ for management.

\section{The Obstacles of Kemitraan Bumidipa Success}

Kemitraan Bumidipa is set to be an alternative of financing for shrimp farmers in Dipasena as they couldn't access it from formal capital institution. It's expected that the capital given will stimulate shrimp farming performance in order to be successful. However, on its application, there are some factors that might cause failure of the program. These factors are as follows:

\section{a. Farming Environment}

In recent periods the productivity of shrimp farming were sharply decreased due to environment factors. Basically, shrimp cultivation are vulnerable to changes in natural conditions such as changes in the weather, the season and the condition of pond. Dipasena environment is untreated well so it caused problems such as water pollution and made cultivation be not conducive. Besides, the majority of shrimp farmers still rely on the chemicals product that contribute to environmental pollution. The emergence of shrimp disease as a derivation of the polluted environment became main cause of cultivation failure. Currently, shrimps were attacked by a disease called white feces disease (Telek Putih) that is caused by virus. This virus spreads rapidly and usually affects the shrimp aged 20-30 days. The symptoms are the shrimps wouldn't be fed, particularly in the evening and shortly floating white feces on the water. Then, many shrimps died before harvest time. While the shrimp farmers don't have accurate diagnosis to tackle the problem, it causes the loss of their farming business.

b. Technical Problem

Infrastructure and technical problem also have contribution on the failure of shrimp cultivation of members. Limited infrastructure and farming technique that is only based on the farmers experience caused the shrimp cultivation process do not meet its standard operational prosedure. As the 
consequence, it's hard to control and predict the result of shrimp farming business.

c. Shrimp Price Fluctuation

Another factor which caused the failure of shrimp farming business in general is fall in shrimp prices. That is mainly due to the oversupply of shrimps in domestic market. On the other hand, the operational cost of shrimp cultivation remains constant. As the result, net income received by shrimp farmers reduced dramatically.

According to Amri and Kanna (2008), vaname shrimp price in the domestic market is still fluctuating at the moment looks very high. When it was first cultivated in Indonesia, the price of vaname shrimp could reach $\mathrm{Rp} \mathrm{70,000} \mathrm{/} \mathrm{kg,} \mathrm{even} \mathrm{more.} \mathrm{However,}$ as many farmers switched to cultivate this shrimp, the price then falls as the the effect of oversupply.

d. Moral Hazard Problem

Member's dishonesty is a serious problem facing the Partnership Bumidipa. As explained before, the member who suffered losses in farming business do not bear the risk as the result of CRU mechanism. Finally, there are some members who conducted moral hazard act such as falsify their farming result and sold saprotam (feed, drugs) provided to external parties without any confirmation to management. These practices are not only cause the loss for Kemitraan Bumidipa, but also the other members as a result of the decline in the program's ability to finance them. Actually, moral hazard problem may also arise because of the difficulty to supervise all members of the the program that spread randomly in Dipasena.
Sadr and Iqbal (2000) stated that the strategies to minimize the problem of moral hazard were the increase intensive supervision and monitoring of the implementation of the project or business. The effort is still required even though the aggreement among the parties involved has done well. Monitoring would be considered as extra costs but it should also be seen as an investment to build a knowledge base about the quality of entrepreneurs and projects. It is also in line with Ahmed (2000) who found that random auditing produces an incentive structure in reducing the moral hazard problem. In addition to the threat and reward or penalty, random audits also provide incentives for businesses to not report a lower profit than the actual situation.

\section{Analysis of Effectivity on Profit-Loss Sharing Financing Program}

Analysis of effectivity on financing managed by Kemitraan Bumidipa is examined based on the perception of its members. In this study, the effectiveness of the program are assested based on 4 aspects/stages, namely the application process, realization process, repayment of financing, and its impact perceived by members.

\section{Analysis of Effectivity on Application Aspect}

The application process is the first stage that has to be fulfilled by shrimp farmers who want to be members of Kemitraan Bumidipa. The indicators used in this stage are the requirements of application, the procedure of financing, and the investment given by members in order to get financial services. 
Table 1. Analysis of Financing Effectivity on Application Stage

\begin{tabular}{llcccc}
\hline No. & \multicolumn{1}{c}{ Indicator } & $\begin{array}{c}\text { Score A } \\
\mathbf{( 3 )}\end{array}$ & $\begin{array}{c}\text { Score B } \\
\text { (2) }\end{array}$ & $\begin{array}{c}\text { Score C } \\
\text { (1) }\end{array}$ & Total \\
\hline 1 & Requirement of Application & 99 & 1 & 0 & 299 \\
\hline 2 & Procedure of Financing & 95 & 5 & 0 & 294 \\
\hline 3 & Minimum Amount of Investment & 100 & 0 & 0 & 300 \\
\hline Total Score & & & & 893 \\
\hline
\end{tabular}

Source: Primary Data; Score 1, Score 2, Score 3 (respondent)

Where: Score 1 for answer (number 1 ) difficult, (number 2) slow, (number 3) high

Score 2 for answer (number 1, 2, dan 3) moderate

Score 3 for answer (number 1) easy, (number 2) fast, (number 3) low

Based on Table 1 it is clearly stated that, the requirements of application process on Kemitraan Bumidipa is relatively easy. The shrimp farmers only needed a photocopy of ID card, letter of recommendation from the local village, and Sharia bank account that has been provided by management of the program in order to apply the financing.

Furthermore, there is a requirement to open the Syariah Mandiri Bank account with certain balance. One of the main purpose of the account is as investment for the members. This fund is then collected and managed by the management. Besides, the existence of this account also makes the accounting system of the program be more professional and transparent. From Table 1, all respondents said that the minimum investment needed to open account is relatively low, which is only Rp200.000, - to get financing with amount approximately of $\operatorname{Rp} 40$ million. Overall, the application process of Kemitraan Bumidipa is effective with score of 893.

\section{Analysis of Effectivity on Realization Aspect}

In this study, the assessment of the effectiveness of the realization stage is determined by 3 indicators, namely the realization of financing (procurement of financing), the administrative costs during the realization of financing or upon saprotam procurement, as well as the ability of the program to meet the financing needs.

Table 2. Analysis of Financing Effectivity on Realization Stage

\begin{tabular}{cccccc}
\hline No. & Indicator & $\begin{array}{c}\text { Score A } \\
\mathbf{( 3 )}\end{array}$ & $\begin{array}{c}\text { Score B } \\
\mathbf{( 2 )}\end{array}$ & $\begin{array}{c}\text { Score C } \\
\mathbf{( 1 )}\end{array}$ & Total \\
\hline 1 & Realization of Financing & 61 & 20 & 19 & 242 \\
\hline 2 & Administration Cost & 100 & 0 & 0 & 300 \\
\hline 3 & Ability to Fulfil Financing Need & 73 & 27 & 0 & 273 \\
\hline \multicolumn{6}{c}{ Rata-Rata Score } \\
\hline
\end{tabular}

Source : Primary Data; Score 1, Score 2, Score 3 (respondent)

Where : Score 1 for answer (number 1) slow, (number 2) high, (number 3) able

Score 2 for answer (number 1, 2, and 3) moderate

Score 3 for answer (number 1) fast, (number 2) low, (number 3) unable

Table 2 shows that $19 \%$ of respondents said relatively long with more than 1 month since it is that the idle time of financing realization is proposed, and $20 \%$ of respondents said that the 
idle time is moderate with a month. While $61 \%$ of respondents said that the financing realization is quite fast with less than a month. This is because the limited amount of the capital to fund a lot of members simultaneously. So, the management set the rotation of capital among its member and it causes idle time for realization process.

In terms of program ability to fulfill financing need, as many as $27 \%$ of respondents said that the amount of capital given has barely fitted members' need on financing. While $73 \%$ of respondents consider that this program is capable to fulfill the financing need. Overall, Kemitraan Bumidipa is relatively effective in realization stage with score 815 .

\section{Analysis of Effectivity on Repayment Aspect}

In Kemitraan Bumidipa, repayment of financing is not conducted by paying money directly as applied by financial institutions in general. However, it is done by selling their crops through the management to the buyer at the end of the cultivation period (harvest). The maximum period for cultivation is about 85 days, which is determined by management. Then, the calculation of profit sharing could be done as describe previously. Therefore, the effectivity of Kemitraan Bumidipa in repayment stage can be determined by several indicators, namely the amount of deduction in calculation of net income from the revenue (CRU, infaq, and other dues), the period of cultivation set, as well as the profit proportion for management and investor.

Table 3. Analysis of Financing Effectivity on Repayment Stage

\begin{tabular}{llcccc}
\hline No. & \multicolumn{1}{c}{ Indicator } & $\begin{array}{c}\text { Score A } \\
\mathbf{( 3 )}\end{array}$ & $\begin{array}{c}\text { Score B } \\
\mathbf{( 2 )}\end{array}$ & $\begin{array}{c}\text { Score C } \\
\mathbf{( 1 )}\end{array}$ & Total \\
\hline 1 & $\begin{array}{l}\text { Amount of CRU, Infaq, and Other } \\
\text { Dues }\end{array}$ & 68 & 15 & 17 & 251 \\
\hline 2 & Repayment Period & 2 & 81 & 17 & 185 \\
\hline 3 & $\begin{array}{l}\text { Proportion of Profit Sharing for } \\
\text { Management and Investor }\end{array}$ & 92 & 7 & 1 & 291 \\
\hline Total Score & & & & 727
\end{tabular}

Source : Primary Data; Score 1, Score 2, Score 3 (respondents)

Where : Score 1 for answer (number 1 ) high, (number 2) short, (number 3 ) high

: Score 2 for answer (number 1, 2, and 3) moderate

: Score 3 for answer (number 1) low, (number 2) long, (number 3 ) low

Based on Table 3, 68\% of respondents stated that the amount of deduction, especially CRU is burdensome. That is because they understand that the CRU fund is used to cover losses of the members failed in business. This is the commitment of the members to bear each other (tabarru') and help each other (ta'awun). While zakat is a form of fulfillment of sharia compliance. On the other hand, $15 \%$ of respondents said that the deduction, particularly CRU is quite burdensome and $17 \%$ of respondents stated that the amount of deduction is onerous. This is because the percentage of CRU is $10 \%$ of the total cost that make it high.

In terms of cultivation period, $81 \%$ of respondents said the time limit set by the management was moderate, while $17 \%$ of respondents said it was too fast. Determination of the maximum period of 85 days of cultivation is based on projections of the management of the standard cultivation time and capital has to be rotated in order to finance other members. Therefore, it's better if the management could determine the maximum number of members 
that fit with the availability of capital so the financing could be done optimally.

In terms of profit proportion for management and investor partners, as many as $92 \%$ of respondents stated that the proportion is low. This proves the commitment of Kemitraan Bumidipa in the welfare of its members by providing a large portion of the profit share. In total, Kemitraan Bumidipa is relatively effective at the repayment stage with score 727.

\section{Analysis of Effectivity on Impact for Business Aspect}

On the impact of the financing, the effectiveness of Kemitraan Bumidipa measured by analyzing the development of business, increased profits, and improved members' cultivation asset.

Table 4. Analysis of Financing Effectivity on Impact to Business Condition

\begin{tabular}{llcccc}
\hline No. & Indicator & $\begin{array}{c}\text { Score A } \\
\text { (3) }\end{array}$ & $\begin{array}{c}\text { Score B } \\
\mathbf{( 2 )}\end{array}$ & $\begin{array}{c}\text { Score C } \\
\mathbf{( 1 )}\end{array}$ & Total \\
\hline $\mathbf{1}$ & Business Development & 37 & 38 & 25 & 212 \\
\hline $\mathbf{2}$ & Profit & 31 & 4 & 65 & 166 \\
\hline $\mathbf{3}$ & Asset Increase & 35 & 60 & 5 & 230 \\
\hline Total Score & & & & 608 \\
\hline
\end{tabular}

Source: Primary Data; Score 1, Score 2, Score 3 (respondent)

Where: Score 1 for answer (number 1, 2, and 3) decrease

Score 2 for answer (number 1, 2, and 3) constant

Score 3 for answer (number 1, 2 and 3) increase

According to Table 4 , in terms of business development $37 \%$ of respondents said that there are significant development on their business since they became members of Kemitraan Bumidipa, $38 \%$ of respondents said that there is no development on business while $25 \%$ indicated a decline on it. At the profit level, as many as 31\% of respondents said that there is an increase in profits since they became members of Kemitraan Bumidipa. While $65 \%$ of respondents actually stated a decline in profits and the rest stated that it tends to be constant. In terms of the increase in assets, 35\% of respondents said that there is an increase in assets, especially shrimp cultivation asset as they became members of the program. While $60 \%$ of respondents said there has been no increase in assets and 35\% of those surveyed consider their farming assets increased due to their success in business

Undeveloped Business is not caused by lack of good financing managed by Kemitraan

Bumidipa, but more likely because it happened shrimp farming failure for recent periods. Less

development of the cultivation is caused by natural factors such as unstable of farming environments well as shrimp disease which occurred in recent periods have led to the failure of cultivation. In addition, many members are still farmed shrimp without following standard of cultivation as described previously. Therefore, it's needed for intensive assistance conducted by the management so that the members can do shrimp cultivation based on its standard. Overall, Kemitraan Bumidipa still quite effective in providing the impact on business conditions with a score of 608 .

\section{Recapitulation of Financing Effectivity on All Aspects}

Total average score of the overall financing aspect amounted to 760.7. The data is shown in 
Table 5. The result of recapitulation indicates that the financing managed by Kemitraan Bumidipa is classified as effective. However, the impact of the financing still has a low value sufficient effectiveness. This is because there is a failure of shrimp farming of the members in recent periods.

Table 5. Recapitulation of Respondents' Perception on Financing Effectivity

Source: Primary Data

\begin{tabular}{lll}
\hline No. & Aspect & Score \\
\hline 1 & Application Process & 895 \\
\hline 2 & Realization Process & 813 \\
\hline 3 & Repayment Process & 727 \\
\hline 4 & Impact on Business & 608 \\
\hline 5 & Average of Score & 760.7 \\
\hline
\end{tabular}

\section{Impact of Profit-loss Sharing Financing on Poverty Indices of Shrimp Farmers}

Paired T-test

Paired $\mathrm{t}$ tests were used to determine the difference in members' income between before and after getting financing. The formula is as follows (Walpole 2005):

T-test hypothesis:

$\mathrm{H}_{0}: \mu=0$

$\mathrm{H}_{1}: \mu_{\mathrm{d}} \neq 0$

T-test statistic:

$$
t_{\text {hit }}=\frac{d-\mathrm{d} 0}{\mathrm{sd} / \sqrt{\mathrm{n}}}
$$

Where:

$$
\begin{aligned}
& d^{-}=\text {the difference of income } \\
& \mathrm{s}_{\mathrm{d}}=\text { standard deviation } \\
& \mathrm{n} \quad=\text { number of observation }
\end{aligned}
$$

\section{T-test criteria:}

$t_{\text {hit }}<t_{\text {table: }} \mathrm{H} 0$ is not rejected, means there are no significance difference of income before and after getting financial service at the significance level of $1 \%$

$t_{\text {hit }}>t_{\text {table: }} H_{0}$ is rejected, means there are significance difference of income before and after getting financial service at the significance level of $1 \%$
Based on this calculation, the value of $t_{\text {hit }}$ is -4.2125 , where the absolute value $|-4.2125|=$ 4.2125 , which more than table value of 2.576 . It means that there is significance difference of income's member between before and after getting financial service at the significance level of $1 \%$. With $t_{\text {hit }}$ value is negative, it means there is a decrease in their income after getting the financial service from Kemitraan Bumidipa instead.

\section{Analysis of Poverty Indices Change on Shrimp Farmers}

After analyzing the income difference by paired $\mathrm{t}$ test, the assessment using poverty indicators is conducted to see clearly the change of poverty indices in shrimp farmers. According to Table 6, the headcount ratio value before becoming a member of Kemitraan Bumidipa is 0,08 , which means that only $8 \%$ of members' family classified as poor according to the household poverty line. After getting financial services, this index increased to 0.33 . While the value of poverty gap index increased from $\mathrm{Rp}$ 212,833 to Rp423,393. That means the average difference between poor shrimp farmers income and the poverty line is Rp206,539 before becoming a member of the program. Then, it increased to Rp417,099 after getting financial 
service. The same result happened to income gap index where it rose from 0.19 to 0.38 .

Table 6. Poverty Indices Comparison Before and After Being Member

\begin{tabular}{cccc}
\hline Poverty Index & Before & After & Difference \\
\hline $\mathbf{H}$ & 0.08 & 0.33 & 0.25 \\
\hline P1 (Rupiah) & $\mathbf{2 1 2 , 8 3 3}$ & $\mathbf{4 2 3 , 3 9 3}$ & $\mathbf{2 1 0 , 5 6 0}$ \\
\hline $\mathbf{I}$ & 0.19 & 0.38 & 0.19 \\
\hline P2 & 0.04 & 0.21 & 0.17 \\
\hline $\mathbf{G}_{\mathbf{p}}$ & 0.32 & 0.44 & 0.12 \\
\hline
\end{tabular}

The sen index or severity poverty index also increased from 0.04 to 0.21 after the shrimp farmers became members of the program. To see if there are gaps aquaculture farmers income both before and after a member of the program, the analysis used Gini coefficient of the poor $\left(G_{p}\right)$. $G_{p}$ value shrimp farmers before becoming a member of the partnership is at 0.32 . That is, the income gap of shrimp farmers before becoming a member of the partnership moderate. After becoming a member of the program, this gap increased to 0.44 . This means fish farmer's income gap actually increased after a member of the partnership. Nevertheless, the income gap is still relatively moderate for shrimp farmers either before or after a member of the program.

The increase in the value of the indices of poverty in the post shrimp farmers become members of the partnership is due to the decrease in revenue received shrimp farmers at the time a member of Kemitraan Bumidipa. While the decline in farmers' income is caused by the failure of the shrimp cultivation that are generally experienced by shrimp farmers Dipasena in recent periods. So, this condition is not happened because they became members of the program.

\section{CONCLUSION AND RECOMMENDATION}

\section{Conclusion}

Based on the analysis result discussed in previous chapter, it revealed that the core values of Kemitraan Bumidipa are the profit sharing system that based on actual profit of shrimp farmers business, the collaboration with some parties include sharia bank to provide professional financial services, the model of joint liability reflected from the mechanism of CRU (Cadangan Rasio Usaha) as investment guarantee, and the right form of financing that direct to productive purpose. In other hand, the factors that could cause failure of the program are related to farming business; namely the the unstable environment of shrimp farming, technical problem of shrimp farmers, and the decreased of shrimp's price in domestic market. Another factor is the moral hazard behavior of its members. According to effectivity analysis, overall this program has been effective. However, there are some indicators such as payback period and the impact of financing that should be optimized. Based on poverty indices result, headcount ratio index $(\mathrm{H})$, poverty gap indiex $\left(\mathrm{P}_{1}\right)$, income gap index $(\mathrm{I})$ and sen index of farmer increase after becoming members of Kemitraan Bumidipa as the result of the failure of their shrimp's cultivation.

\section{Recommendation}

According to the conclution of this research mentioned before, there are some recommendations that may be useful for Islamic financial sector, coastal societies empowerment, and any related research in the future:

1. Sharia microfinance institution should be more selective in choosing its clients in order to avoid moral hazard act. 
2. In case of financing, it should be a supervision mechanism to prevent the clients from moral hazard act.

3. Government and related institutions must give support and assistance for coastal societies in case of its empowerments and economy improvement.

4. There is a need for further research particularly related to the unstable environment of shrimp farming and the fluctuation of shrimp's price.

\section{REFERENCES}

Afzalurrahman. (1997). Muhammad sebagai Seorang Pedagang [Muhammad as A Trader]. Jakarta (ID): Yayasan Swarna Bhumi.

Agustina R. (2010). “Analisis Kualitas Pembiayaan dan Pengaruhnya terhadap Efektivitas Pendapatan pada PT. BPR Syariah PNM Al-Ma'soem Bandung. [Analysis of Financing Quality and Its Effect on Income Effectivity on PT BPR Syariah PNM Al-Ma'soem Bandung]". Available at: http:/ dir.unikom.ac.id/s1final-

project/fakultasekonomi/akuntansi/ 2010

/jbptunikompp-dgl-ratihagust-21817/19 jurnal.docx / pdf/19-jurnal. pdf

Ahmed H. (2000). Incentive-compatible profitsharing contracts: a theoretical treatment, in: Iqbal M, LIewellyn DT, editor. Islamic Banking and Finance: New Perspective on Profit- Sharing and Risk [internet]. The Fourth International Conference on Islamic Economics and Banking. 2000 Agust 13-15; Loughborough University, United Kingdom. Loughborough University (UK): Edward Elgar Publishing Limited. Hlm 40-56. Available at:

http://www.iefpedia.com/english/wpco ntent/uploads/2013/06/International_C
onference_on_Islamic_Economics_andBo okos.org_.pdf

Amri, K. (2008). Budi daya Udang Vaname secara Intensif, Semi Intensif, dan Tradisional [Vaname Shrimp Cultivation: Intensive, Semi Intensive, and Traditional]. Jakarta (ID): P.T. Gramedia

Anjani. (2013). “Analisis Efektivitas Pembiayaan Syariah bagi Sektor Pertanian pada KBMT Ibadurrahman, Ciawi, Bogor [Analysis of Effectivity of Sharia Financing for Agriculture Sector on KBMT Ibadurrahman]". [Thesis]. Bogor (ID): Institut Pertanian Bogor.

Ariansyach. (2009). "Pengaruh Program Pemberdayaan Ekonomi Masyarakat Pesisir (PEMP) terhadap Pendapatan Masyarakat Pesisir Kabupaten Sukabumi, Provinsi Jawa Barat [The Effect of Economic Empowerment Program for Coastal societies on their Income in Sukabumi Regency, West Java]". [Thesis]. Bogor (ID): Institut Pertanian Bogor.

Azzahrah. (2014). “Analisis Faktor-Faktor yang Memengaruhi Permintaan Pembiayaan Mudharabah bagi UMKM dan Efektivitas Pembiayaan Mudharabah bagi UMKM pada BMT X Jakarta [Analysis of Factors Affect the Demand of Mudharabah Financing for UMKM and It's Effectivity for UMKM in BMT X Jakarta]". [Thesis]. Bogor (ID): Institut Pertanian Bogor.

BAKOSURTANAL, Pusat Survei Sumber Daya Alam Laut. 2006. Buku Tahunan [Annual Book]. Bogor. Available at: www.bakosurtanal.go.id

Beik, et al. (2013). Pengembangan Konsep Islamic Poverty Line [The Concept Development of Islamic Poverty Line]. [Final Report]. Lembaga Penelitian dan Pengabdian kepada Masyarakat, Institut Pertanian Bogor. 
Badan Pusat Statistik Provinsi Lampung. (2014).

Garis Kemiskinan Provinsi Lampung menurut Kabupaten/Kota, 2008-2013

[Poverty Line of Lampung Province Based on Regency/City, 2008-2013]. Available at: lampung.bps.go.id

Clark, S. et al. (1981). On indices for the measurement of poverty. The Economic Journal, 91(362), 515-526.

Direktorat Jenderal Pengolahan dan Pemasaran Hasil Perikanan Kementerian Kelautan dan Perikanan. 2011. P2HP Dalam Angka 2010 [P2HP in Number 2010]. Available at: kkp.go.id

Effendi J. (2013). The Role of Islamic Microfinance in Poverty Alleviation and Environmental Awareness in Pasuruan, East Java, Indonesia. [Dissertation]. Available at: http:/ / www.sub.uni-goettingen.de

Fauzi A. (2005). Kebijakan Perikanan dan Kelautan: isu, sintesis, dan gagasan [Policies of Fisheries and Marine: Issue, Syntesis, and Idea]. Gramedia Pustaka Utama: Jakarta (ID)

Ghafar A. I. (2006). Does the Islamic financial system design matter? Emerald Available at: http:/ / www.1stethical.com /wpcontent/uploads/2010/07/Does_the _Islamic_financial_system_design_matter. pdf

Ita S. and Rahman A. (2011). “Evaluasi Penerapan Pembiayaan Mudharabah dan Pengaruhnya terhadap Laba Perusahaan [Evaluation of Application of Mudharabah Financing and Its Effect on Company Profit]". [Journal]. Jurnal Ilmiah Ranggadang Volume 11, Nomor 3, April 2011.

Jannah. (2014). 25\% Penduduk Miskin adalah Nelayan. [25\% of Poor Societies were Fishermen]. Available at: http:/ / economy.okezone.com/read/2014 /11/24/320/1069854/25-pendudukmiskin-adalah-nelayan. [4 Juli 2015]

Otoritas Jasa Keuangan. (2008). Undang-Undang Nomor 21 Tahun 2008 tentang Perbankan Syariah. Available at: http://www.ojk.go.id/undang-undangnomor-21-tahun-2008-tentang-perbankansyariah

Rodiana. (2014). “Efektivitas Penerapan Bayar Pascapanen pada Pengembalian Pembiayaan Akad Murabahah Pertanian Padi di BMT As-Salam, Kramat, Demak. [The Effectivity of Post-Harvest Repayment on Murabahah Financing in BMT As-Salam, Kramat, Demak]". [Thesis]. Bogor (ID): Institut Pertanian Bogor.

Sadr K. and Iqbal Z. (2000). Choice between debt and equity contracts and asymmetrical information: some empirical evidence. In: Iqbal M, Llewellyn DT, editor. Buku_Islamic Banking and Finance: New Perspective on Profit- Sharing and Risk. The Fourth International Conference on Islamic Economics and Banking. 2000 Agust 13-15; Loughborough University, United Kingdom. 23 Loughborough University (UK): Edward Elgar Publishing Limited. Hlm 40-56. Available at:

http://www.iefpedia.com/english/wpcontent/uploads/2013/06/International_ Conference_on_Islamic_Economics_andB ookos.org_.pdf

Sajogyo. (1996). Memahami dan Menanggulangi Kemiskinan di Indonesia [Understanding and Eradicating Poverty in Indonesia]. Bogor (ID): P.T. Grasindo.

Sugiyono. (2010). Memahami Penelitian Kualitatif [Understanding Qualitative Research]. Bandung (ID): Alfabeta. 
Sugiyono. (2011). Metode Penelitian Kuantitatif

Kualitatif dan RED [Quantitative, Qualitative, and RED Research Method]. Bandung (ID): Alfabeta.

Soemitra A. (2009). Bank dan Lembaga Keuangan Syariah [Bank and Sharia Financial Institution]. Jakarta (ID): Prenada Media Group.

Walpole R.E. (2005). Pengantar Statistika Edisi ke-3. [Statistic Method: Third Edition]. Jakarta (ID): P.T. Gramedia.

Yousfi O. (2013). Does PLS solve moral hazard problem? JIEBF. Available at: http://www.isu.ac.ir/farsi/Academics/e conomics/edu/dlc/2rd/02/instructor/ar t2.pdf 